\title{
BERPIKIR POSITIF TERHADAP PENYANDANG HIV DAN AIDS
}

\author{
Farhin Bala Agubay \\ Fakultas Psikologi \\ Universitas Ahmad Dahlan \\ Balafarhin8@gmail.com
}

\begin{abstract}
Abstrak
Penyandang HIV dan AIDS memiliki permasalahan mengenai berpikir positif. Tujuan penulisan ini adalah untuk mengetahui gambaran berpikir positif pada penyandang HIV dan AIDS dan mengidentifikasikan cara berpikir positif penyandang HIV dan AIDS. Subjek penelitian yang digunakan berjumlah 3 orang yang berada dalam komunitas Victory plus di Yogyakarta. Metode pengumpulan data yang digunakan adalah observasi dan wawancara. Hasil observasi dan wawancara yang diperoleh bahwa kemampuan berfikir positif seorang yang mengidap HIV dan AIDS yang terdapat dalam komunitas Victory plus ini merupakan modal utama yang ditanamkan dalam jiwa seorang yang terkena HIV dan AIDS untuk memiliki keberanian dan dukungan dalam mewujudkan cita-cita yang dimiliki serta memiliki keberanian dalam berkomunikasi dengan lingkungan.
\end{abstract}

Kata Kunci: berpikir positif, lingkungan, HIV, AIDS

\section{PENDAHULUAN}

Di seluruh dunia ini tau ada beberapa virus yang sangat terkenal saat ini,dan yang paling berbahaya salah satunya adalah Human Immunodeficiency Virus (HIV) yang menyebabkan penyakit Acquired Immune Deficiency Syndrome (AIDS).Seperti yang kita tahu AIDS pertama kali ditemukan di kota San Francisco, Amerika Serikat. Penyakit ini muncul karena hubungan seksual (sodomi) yang dilakukan oleh komunitas kaum homoseksual (Hawari, 2004). Informasi dari UNAIDS menyatakan bahwa sampai tahun 2010 jumlah penderita HIV mencapai 34 juta orang di dunia.Kondisi seperti ini membuat mereka mengalami perubahan secara cepat.

Human Immunodeficiency Virus (HIV) adalah retrovirus yang termasuk dalam famili lentivirus. HIV menyebabkan beberapa kerusakan sistem imun dan menghancurkannya. Acquired Immunodeficiency Syndrome (AIDS) adalah sekumpulan gejala dan infeksi yang timbul karena rusaknya sistem kekebalan tubuh manusia akibat infeksi virus HIV. AIDS diartikan sebagai bentuk paling berat dari keadaan sakit terus-menerus yang berkaitan dengan infeksi HIV (Smeltzer, 2001).

Dewasa ini Indonesia sedang dihadapkan pada masalah kesehatan masyarakat yang sangat kompleks. Lebih buruknya lagi pola penyakit yang diderita masyarakat Indonesia adalah 
infeksi menular seperti infeksi saluran pernapasan akut (ISPA), tuberkulosis, malaria, dan penyakit kulit. Selain itu Indonesia juga menghadapi emerging diseases seperti demam berdarah dengue, HIV/AIDS, chikungunya, Severe Acute Respiratory Syndrom (SARS). Penyakit yang paling parah dengan ancaman kematian yang belum ada obatnya adalah HIV (Kurniasih, 2007).

Individu yang menderita HIV/AIDS diharapkan mampu beradaptasi dilingkungan asal mereka dengan harapan mereka akan tetap mampu bersosialisasi dengan masyarakat secara normal, agar mempunyai pikiran positif mengenai diri, orang lain, dan lingkungan disekelilingnya. Tentama (2012) mengatakan bahwa indivdiu yang berfikir positif akan merasakan dampak yang luar biasa terhadap diri mereka sendiri maupun lingkungan mereka. Selain itu, Tentama (2010) mengungkapkan manfaat berfikir positif ini akan membawa dampak kesehatan psikologis individu dalam jangka panjang.

\section{PEMBAHASAN}

Berfikir positif adalah sikap mental sesuatu yang melibatkan suatu pemikiran,kata-kata dan gambaran yang membangun bagi perkembangan pikiran (Arifin,2011) Individu yang berkepribadian yang positif mengerti bahwa sesaat saja kehilangan harapan akan menghancurkan hidupnya. Tanpa harapan positif sama saja menjerumuskan kita ke dalam kesulitan berkepanjangan yang mengakibatkan pikiran negatif dan perasaan negatif. Oleh karena itu orang

yang berkpribadian yang positif akan terus bertarung ke titik darah penghabisan. Dari penjelasan diatas harusnya kita yang memulai harus berani menghadapi resiko yang kita perbuat,jangan sampai mempunyai pikiran negatif dan perasaan negatifuntuk hidup.tetapi selalu berpikir positif untuk hidup dan harus selalu berjuang untuk menghadapinya.

Menurut pandangan Hurlock (2004)konsep diri berdasarkan perkembangannya menjadi konsep skunder,primer.konsep skunder adalah konsep yang berdasarkan di dalam rumah yang berhubungan dengan keluarga dan saudara. Menurut Stalard (2005) berpikir positif merupakan pelatihan berpikir positif dalam penelitiannya berupa materi-materi yang tercakup pada aspekaspek berikut ini. (a) Kepuasan hidup, yaitu merasakan bagaimana puasnya mendapatkan kepuasan yang kita peroleh dari harta maupun dari prestasi. (b) Harga diri mengaruh dengan karakteristik dirinya sendiri dan menerima kualitas dirinya. (c) Optimisme menunjukkan kemampuan ingin melakukan sesuatu entah itu tentang tujuan hidup atau untuk bertahan hidup. 
Menurut Peale (1995) berpikir positif adalah aplikasi langsung yang praktis dari teknik spiritual diri sendiri untuk mengatasi kemenangan dalam kepercayaan serta menciptakan suasana yang menguntungkan bagi perkembangan hasil yang positif. Berpikir positif banyak memberikan manfaat terhadap komunitas-komunitas yang memiliki keterbatasan tertentu. Diantara manfaatnya adalah berpikir positif mempengaruhi penerimaan diri pada penyakit yang sulit tersebut. (Tentama, 2010: Tentama, 2014). Berpikir positif dapat membawa pengaruh baik untuk seseorang yang mengidap virus hiv dan aids, dengan berpikir positif akan membuat kondisi tubuh menjadi lebih nyaman,karena pikiran negatif yang akan hilang dengan sendirinya sehingga membuat kondisi tubuh menjadi lebih nyaman.

Cara yang bisa dilakukan untuk menumbuhkan pikiran positif adalah dengan mendapatakan suport dari orang-orang disekitarnya. Agar kehidupan bisa optimal di masyarkat perlu mengembangkan kemampuan mengelola diri agar selalu berpikir positif terhadap keadaan dirinya. (Tentama, 2012). Keluarga sebagai bangunan paling dasar kehidupan sosial adalah tonggak peradaban sebuah bangsa. Aplikasi berfikir positif bagi penyandang hiv dan aids ini sangat penting untuk melakukan musyawarah untuk berusaha saling menyempurnakan dan tidak saling menyalahkan. Orang terdekat seseorang yang bukan dari anggota keluarga yang akrab dengan seseorang/individu yang bersngkutan.Biasanya orang terdekat ini mengajak melakukan sesuatu yang sering merka lakukan,dengan berpikir positif terhadap orang terdekat ini dapat mengatasi tingkat emosionalnya dan mampu berpikir jernih sebelum memutuskan tindakan. Relasi atau hubungan ini sangat berpengaruh untuk kehidupan dan menjadi salah satu pokok kebutuhan manusia.Aplikasi relasi ini sangat berpengaruh untuk berpikir positif bagi penyandang hiv dan aids untuk membuktikan kualitas dan dedikasinya dan mengajak bekerja sama untuk melakukan hal yang baik bagi dirinya.

\section{SIMPULAN}

Individu yang mempunyai kepribadian yang positif mengerti bahwa sesaat saja kehilangan harapan akan menghancurkan hidupnya. Tanpa harapan positif sama saja menjerumuskan kita ke dalam kesulitan berkepanjangan yang mengakibatkan pikiran negatif dan perasaan negatif. Oleh karena itu orang yang berkepribadian yang positif akan terus bertarung ke titik darah penghabisan. Seharusnya kita yang memulai harus berani menghadapi resiko yang 
kita perbuat, jangan sampai mempunyai pikiran negatif dan perasaan negatif untuk hidup tetapi selalu berpikir positif untuk hidup dan harus selalu berjuang untuk menghadapinya.

\section{DAFTAR PUSTAKA}

Arifin, Y. (2001) 100\% Bisa selalu berpikir positif. Jogjakarta: Diva Press

Hurlock. E. B. (2004) Psikologi perkembangan sepanjang rentang kehidupan, (ed.5) (Istiwidayanti dan Soedijarwo). Jakarta: Erlangga

Peale, N. V (1996). Berpikir positif. Jakarta: Binarupa Aksara

Stallard, P. (2005) A Clinician”s guide to think good-feel good using cbt with children and young people. West sussex: John Wiley and Sons

Tentama, F. (2010). Berpikir positif dan penerimaan diri pada remaja penyandang cacat tubuh akibat kecelakaan. Humanitas VII(1), 66-75.

Tentama, F. (2014) Hubungan positive thinking dengan self-acceptance pada difabel (bawaan lahir) di SLB negeri 3 Yogyakarta. Jurnal psikologi integratif, 2(2), 1-7

Tentama, F. (2012). Membangkitkan pikiran positif difabel. Republika, 76 